DOI: $10.19195 / 0137-1134.106 .24$

\title{
ANDRZEJ JAROSZEK
}

\section{JAK POWSTAWAŁY „USTAWY POŻARNICZE” — WSPOMNIENIA}

Pomysł nowych ustaw pożarniczych, czyli wizja koniecznych przemian w systemie pożarnictwa, dotyczyć miał losu kilku tysięcy osób, głownie zatrudnionych w służbach resortowych ochrony przeciwpożarowej i nie tylko. Dla zachowania pewnego porządku w mojej relacji należy przypomnieć, że wydarzenia, jakie zapoczątkowały przemiany ustrojowe i polityczne oraz reformy gospodarcze w roku 1989/90, były co do skali i rozmiaru niespotykane w historii powojennej Polski. Tempo zmian szokowało wiele osób czynnych zawodowo, jednak w krótkim czasie przekonaliśmy się, że były to zmiany nieodwracalne. Istotnie w tamtym okresie „centrala strażacka” usiłowała kolejny raz poprawić ustawę z dnia 12 czerwca 1975 r. o ochronie przeciwpożarowej ${ }^{1}$, której pierwowzorem była ustawa z dnia 13 marca 1934 r. o ochronie przed pożarami i innymi klęskami żywiołowymi ${ }^{2}$. Ze względu na ograniczoność formy trudno jest wykazywać różnice i podobieństwa tych ustaw.

Inny bardzo poważny (moim zdaniem) kłopot dla ,centrali” stanowił dekret z dnia 27 grudnia 1974 r. o służbie funkcjonariuszy pożarnictwa ${ }^{3}$. Ów dekret był namiastką pragmatyki strażackiej — nie tylko uchybiał powadze służby, ale plasował nas bardzo daleko w stosunku do innych służb mundurowych z tamtego okresu. O pragmatyce równej lub choćby zbliżonej do służb z tamtego okresu nie marzyły najwybitniejsze osobistości pożarnictwa polskiego, choć nie wykluczam, że w snach nocy letniej, podczas wypoczynku w ośrodkach rządowych takie sytuacje mogły mieć miejsce - istotnie. Wypada jedynie dla zasady przypomnieć, że przepisy rangi dekretu z mocą ustawy były wydawane przez Radę Państwa i musiały być przedstawione Sejmowi na najbliższej sesji do zatwierdzenia. Sejm niestety dekret zatwierdził i obowiązywał on z nieistotnymi zmianami do roku 1991. W drugiej połowie 1990 r. miałem przyjemność poznać osobiście

\footnotetext{
1 Dz.U. Nr 20, poz. 106.

2 Dz.U. RP Nr 41, poz. 335.

3 Dz.U. Nr 50, poz. 321 ze zm.
} 
autorkę projektu dekretu o służbie funkcjonariuszy pożarnictwa śp. doc. dr Janinę Orłowską — dyrektor Departamentu Organizacyjno-Prawnego w Ministerstwie Spraw Wewnętrznych. Nie ukrywam, że Janina Orłowska wyraziła ubolewanie z powodu niedoskonałości tego przepisu, tłumacząc, że opracowanie projektu dekretu było pierwszym jej poważnym zleceniem jako początkującego prawnika w ministerstwie.

Czy godnymi ubolewania pozostają niezmiennie fakty, które nie najlepiej świadczą o ludziach tamtego okresu? Nie wykluczam, że czynili oni zabiegi i wysiłki, by ten stan prawny zmienić, może - ale bez skutecznie. Pytanie, na które niełatwo znaleźć jednoznaczną odpowiedź, czy podniesienie rangi służby pożarniczej uniemożliwiali ówcześni decydenci partyjni przy udziale czynników rządowych? A może wynikało to z innych przyczyn, których trudno dzisiaj dopatrywać się w postawach ludzi tamtego minionego czasu.

Chęć przygody ma czasami swoistą genezę, występuje bowiem faza planowania, dojrzewania, realizacji i wspomnień. Jeżeli chodzi o planowanie i dojrzewanie, to w moim przypadku trwało to może dwadzieścia lat. Chęć przyczynienia się, aby pełnić służbę w przejrzystej strukturze organizacyjnej, podniesienie rangi zawodu poprzez wprowadzenie pragmatyki służbowej równej innym służbom mundurowym i podporządkowanie pożarnictwa Ministrowi Spraw Wewnętrznych, tkwiło w mojej świadomości prawie od momentu ukończenia (w 1971 r.) Szkoły Oficerów Pożarnictwa. Jestem w stanie zaryzykować twierdzenie, że nie było w Polsce drugiej tak pogmatwanej organizacyjnie struktury, jak pożarnictwo. Jak można było podnieść rangę zawodu, skoro pozorna spójność organizacyjna ochrony przeciwpożarowej była bardziej dorozumiana niż konsekwentna. Istotnie, pożarnictwo było prawie wszędzie, w terenie, jak i w zakładach pracy — takie samo. Trzon pożarnictwa w kraju stanowiła służba terenowa, ale też filarami w organizacji pozostawały służby resortowe. Zarówno jednym, jak i drugim chodziło o to samo, czyli przyczynianie się do podnoszenia poziomu ochrony przeciwpożarowej, zarówno w terenie jak i w zakładach pracy — czyli cel był jeden wspólny dla wszystkich. W praktyce, ale zgodnie z ówczesnym prawodawstwem, Ministerstwu Spraw Wewnętrznych podlegało pięć jednostek organizacyjnych, czyli Komendant Główny, trzy szkoły i Ośrodek Badawczo-Rozwojowy Ochrony Przeciwpożarowej. Pozostali pożarnicy byli zatrudnieni w jednostkach administracji państwowej lub jednostkach resortowych. Każdy z nas na mocy dekretu był pożarnikiem mianowanym, ale zatrudnianym na podstawie umowy o pracę i podlegał przepisom zawartym w kodeksie pracy. $\mathrm{W}$ terenowych jednostkach ochrony przeciwpożarowej była to dość jasna sytuacja, ale w resortowych jednostkach sprawy wyglądały nieco inaczej. Mianowany funkcjonariusz był de facto zatrudniany przez dyrektora danego przedsiębiorstwa lub instytucji, podlegał pracodawcy, ale też wpływ na jego służbę miał inny funkcjonariusz pełniący służbę w jednostce nadrzędnej - na szczeblu zjednoczenia lub ministerstwa. W jednostkach terenowych komendanci wojewódzcy byli pracownikami urzędów wojewódzkich 
jako pracownicy administracji publicznej (państwowej). Na szczeblu urzędów rejonowych komendanci rejonowi już takimi pracownikami nie byli, a przyporządkowane terenowe zawodowe straże pożarne działające przy komendach rejonowych stanowily odwody wszechobecnej w tym czasie Obrony Cywilnej Kraju. Za kuriozalny należy uznać stan prawny zakładów zawodowych straży pożarnej, które w pełnym zakresie finansowane były przez zakłady pracy, w jakich działały, a stan gotowości bojowej tych jednostek był kontrolowany przez komendantów rejonowych straży pożarnej.

W zakładach przemysłowych i w znaczących instytucjach państwowych działali zatrudnieni funkcjonariusze pożarnictwa, do których obowiązków należało między innymi kontrolowanie stanu ochrony przeciwpożarowej. Niezależne zakłady czy też instytucje były systematycznie kontrolowane przez funkcjonariuszy komend rejonowych, a wszczynane postępowania karno-administracyjne (z upoważnienia innego organu) w celu przymuszenia wykonania zaleceń, występowały nader często, bez względu na kondycję finansową zakładu czy instytucji. Szanowny czytelniku - kto z ówczesnych decydentów partyjnych lub czynników rządowych albo posłów mógł ogarnąć to umysłem mimo najszczerszych chęci. Obawiam się, że wyjątkowo cierpliwy i zainteresowany słuchacz po godzinie wykładu na temat organizacji ochrony przeciwpożarowej w kraju i konieczności przeprowadzenia zmian tracił po prostu cierpliwość. Myślę, że wiele osób bez względu na ich rangę i wpływy dochodziło do wspólnego wniosku, że skoro to wszystko jakoś funkcjonuje i wzajemnie przenikając się organizacyjnie uzupełnia, to po co to zmieniać i w imię jakich racji i czyich interesów — przecież władza państwowa była wszechobecna.

W moim przypadku ogromne znaczenie dla rozwoju zarówno zawodowego, jak i intelektualnego miał fakt, że w 1974 r. zrezygnowałem z dalszej służby we Wrocławskiej Komendzie Straży Pożarnych na rzecz Uniwersytetu Wrocławskiego, gdzie przez Głównego Inspektora Ochrony Przeciwpożarowej w Ministerstwie Nauki Szkolnictwa Wyższego i Techniki mianowany zostałem na stanowisko starszego inspektora ochrony przeciwpożarowej. Po dwóch latach służby (taki był wymóg formalny) otrzymałem skierowanie na studia zaoczne, czyli Studium Zaoczne Prawa na Wydziale Prawa i Administracji. Muszę przyznać z pokorą, że świat ludzi nauki, wśród których byli wielcy naukowcy, znani z osiągnięć na wielu uczelniach Europy i USA - mnie przytłaczał. Ja nie miałem ambicji zostać pracownikiem naukowym, ale jako porucznik pożarnictwa byłem zdumiony, zadziwiony i zafascynowany możliwościami świata nauki. Istotnie upłynęło trochę czasu, aż odnalazłem swoje miejsce wśród tych ludzi i jako jeden spośród 1300 pracowników administracji i obsługi uczelni stałem się dobrze znany i spostrzegany przez pracowników naukowych — dyrektorów instytutów, kierowników katedr czy zakładów. Przez cały okres służby na Uniwersytecie utrzymywałem bardzo poprawne kontakty z wieloma pracownikami nauki i administracji. Szczególnie dobrze poruszałem się wśród pracowników Wydziału Prawa i Administra- 
cji, gdzie przez pięć lat studiowałem. Jak się kilka lat później okazało, były to znajomości bezcenne dla dobra przyszłej struktury Państwowej Straży Pożarnej.

Tak dotrwałem na uczelni do 1990 r. Przez cały okres służby na Uniwersytecie pozostawałem również w poprawnych kontaktach koleżeńskich z wieloma oficerami, którzy pełnili służbę w komendzie wojewódzkiej straży pożarnej oraz komendach rejonowych i z dowódcami zawodowych straży pożarnych — potocznie zwanych ZSP. W roku 1990 komendantem rejonowym dzielnicy Wrocław-Psie Pole i dowódcą O/V Zawodowej Straży Pożarnej był Ryszard Januszkiewicz, który dość swobodnie poruszał się po dzielnicy wśród przedstawicieli ówczesnych władz. Na podkreślenie zasługuje, że w dzielnicy działało wiele zakładów przemysłowych o dość dużym zagrożeniu pożarowym. Podobnie jak ja Januszkiewicz wykazywał zaniepokojenie zachodzącymi zmianami (przemianami) zarówno w strefie gospodarczej, politycznej, jak i w służbach mundurowych. Aktywność naszej strażackiej „centrali” w tym zakresie była niewielka. W krótkim czasie do naszego grona dołączyli kolejni zwolennicy przemian w ochronie przeciwpożarowej. Eugeniusz Engel - szef Inspektoratu Ochrony Przeciwpożarowej DDOKP we Wrocławiu i pracownik Inspektoratu, nieżyjący już Stanisław Mierzwa. Do spotkań dochodziło często, ale dyskretnie w obawie przed negatywną reakcją przełożonych. Każdy z nas był przekonany co do jednej słusznej koncepcji — że straż pożarna w całej swej strukturze powinna być podporządkowana Ministrowi Spraw Wewnętrznych, podobnie jak inne służby działające $\mathrm{w}$ tym resorcie. Na przełomie lutego i marca $1990 \mathrm{r}$. uznaliśmy, że nasze grono należy poszerzyć o kolegów z Wałbrzycha. Wówczas komendantem wojewódzkim w Wałbrzychu był Eugeniusz Zajączkowski, a jego zastępcą Józef Modras (mój kolega z roku w czasie studiów w SOP). Świadomość, że kolega Zajączkowski rekomendowany był na to stanowisko przez gen. poż. Andrzeja Stefanowskiego - komendanta głównego, z którym pozostawał w poprawnych stosunkach służbowo-towarzyskich, utwierdziła nas w tym przekonaniu. Do Wałbrzycha pojechał z nami również kol. Wiesław Jaworski. Na szczególne podkreślenie zasługuje nie tylko miejsce w strukturze ówczesnej straży pożarnej osoby kol. Jaworskiego oraz jego aktywność jako działacza NSZZ „Solidarność" w okresie „stanu wojennego" i późniejszym, ale również znajomość z wieloma działaczami tego związku na terenie miasta Wrocławia. Wjeżdżając do Wrocławia, ja i kol. Ryszard byliśmy przekonani, że do naszego grona pozyskaliśmy dwóch zdolnych i doświadczonych kolegów, których nasza koncepcja w pełni zadowalała i którzy zadeklarowali współpracę co do dalszych zamierzeń.

Docierały do nas informacje, że „centrala” podejmuje działania w zakresie reorganizacji komend i zadań w ramach ustawy o ochronie przeciwpożarowej. $Z$ tego naszego początkowego działania zachowały się różne materiały, jak choćby projekt ustawy o urzędzie straży pożarnej, którego zapisy odnosiły się do stworzenia samodzielnej struktury, jej organizacji i zadań. Od początku uważaliśmy, że straż pożarna podlegać ma bezpośrednio MSW na równi z innymi służbami w tym resorcie. Proszę pamiętać również, że w tym okresie obradował już Sejm 
X kadencji oraz Senat I kadencji, a także działał już Związek NSZZ „Solidarność”, który został reaktywowany i zarejestrowany na jesieni 1989 r. Ruch związkowy rozwijał się dynamicznie, co było zauważalne w strukturach terenowych ówczesnych straży pożarnych. Działania Związku były wyraźne i odczuwalne, a ruch zmian kadrowych wchodził w fazę wymiany pokoleniowej. Bardzo ważnym wydarzeniem, którego przebieg bardzo dobrze pamiętam, było zorganizowanie (tak właśnie po reaktywowaniu Związku) pierwszego zjazdu NSZZ „Solidarność” pożarnictwa w marcu 1990 r. w Józefowie. Z Wrocławia uczestnikami (delegatami) był Wiesław Jaworski i Andrzej Abulewicz (delegaci struktury terenowej) i ja, jako delegat służb resortowych. Przebieg zjazdu był dość burzliwy. Myślę, że była to reakcja delegatów na miniony czas niedogodności i niesprawiedliwości. Na zjeździe wybrano przewodniczącego, którym został Krzysztof Wojtulski. Wiceprzewodniczącymi byli: Wiesław Jaworski i Zdzisław Sołowin. Do Rady Krajowej wybrani zostali między innymi Jan Oko, Piotr Kołodziński, Waldemar Kowalak, Andrzej Brand, Jerzy Bazylak i ja.

Podczas obrad miały miejsce dwa dość ważne wydarzenia. Pierwsze dotyczyło zaprezentowania przez przedstawicieli Szkoły Głównej Służby Pożarniczej (między innymi Roguskiego) projektu ustawy o urzędzie ratowniczym jako naczelnym organie administracji państwowej — czyli w randze ministerstwa. Projekt zawierał kilka propozycji o istotnym znaczeniu. Nie wróżono powodzenia co do dalszego wdrażania tego projektu, albowiem w tym czasie rysowała się wyraźnie tendencja do likwidacji czy też łączenia resortów, a o możliwości utworzenia nowego nie mogło być mowy. W mojej ocenie i nie tylko, było to jednak już coś, czym można było zainteresować posłów. Pamiętam, że kol. Zdzisław Sołowin, kol. Roguski, kol. Krzysztof Wojtulski i ja pojechaliśmy do gmachu Sejmu na spotkanie z posłami — w celu zaprezentowania projektu ustawy o urzędzie ratowniczym. Wyjazd był inicjowany przez kol. Sołowina. Jak już wspomniałem, projekt nie znalazł uznania i zainteresowania, bo był niekompletny i tworzył nowy resort. Dość szczęśliwie się złożyło, w moje ręce trafił projekt ustawy o urzędzie ministra spraw wewnętrznych, z którego zapisu wynikała wyraźnie, że Minister Spraw Wewnętrznych sprawuje nadzór nad Policją, Urzędem Ochrony Państwa, Strażą Graniczną i Strażą Pożarną. Po przeczytaniu tego fragmentu byłem zaskoczony i zdumiony, ale wewnętrznie w pełni usatysfakcjonowany. Zapis ten jednoznacznie użyty w formie pojedynczej wskazywał, że chodzi tu o jedną strukturę organizacyjną — czyli Straż Pożarną. Użyta forma tego zapisu, w pełni odpowiadała naszym wyobrażeniom o stworzeniu w kraju jednej struktury Straży Pożarnej, obok takich struktur jak Policja, Urząd Ochrony Państwa i Straż Graniczna, podległych Ministrowi Spraw Wewnętrznych. Wykorzystując miejsce, czyli gmach Sejmu, postanowiłem spotkać się z prof. Januszem Trzcińskim, ówczesnym posłem, ale też dziekanem Wydziału Prawa i Administracji Uniwersytetu Wrocławskiego. Było to krótkie spotkanie, w jego trakcie podzieliłem się informacją na temat tego zapisu, który w pełni odpowiadał naszym wyobrażeniom — omawianym we Wrocławiu. 
Pamiętam do dziś, gdyż takich chwil się nie zapomina, gdy poseł przeczytał wyjęty z mojej ręki oznaczony fragment druku i niemal natychmiast na jego twarzy zarysowało się zdziwienie, spojrzał na mnie (pomyślałem, czy postąpiłem słusznie), przeczytał ten fragment jeszcze raz i powiedział, oddając mi druk projektu: „to tak to rozumiesz” i po chwili dodał: „to niech tak zostanie, skoro jest to po waszej myśli — to działajcie”. Jak byli funkcjonariusze pożarnictwa i obecni strażacy wiedzą, istotnie, nasze działania czynione na podstawie tego zapisu, stały się na tyle skuteczne, że w roku 1991 Sejm uchwalił ustawę o Państwowej Straży Pożarnej podległej MSW z pełną pragmatyką równą pozostałym jednostkom w tym resorcie.

Projekt ustawy o urzędzie ratownictwa nie wzbudził zainteresowania wśród posłów, a my wróciliśmy do Józefowa, gdzie kończył się zjazd. Przed oficjalnym zakończeniem tego zjazdu pozostawiono czas na dyskusję, w trakcie której umożliwiono mi zabranie głosu. Przedstawiłem zebranym wątpliwości wynikające $\mathrm{z}$ aktualnego stanu organizacyjnego ochrony przeciwpożarowej i struktury staży pożarnych w zakładach przemysłowych, które w wielu przypadkach były zagrożone likwidacją. Pamiętam, jak po dłuższej rozmowie i wymianie poglądów oraz informacji z gen. Stefanowskim poza salą obrad, ten wypowiedział wtedy dość przekonywająco słowa, które mnie kompletnie zaskoczyły i zaszokowały: „Panowie, jeżeli macie jakąś wizję zmian, to róbcie coś, bo niebawem, jak tak dalej pójdzie, to przyjdzie nam jeszcze do tego wszystkiego fekalia wywozić". Utwierdziło mnie to w przekonaniu, że Komenda Główna nie dysponuje możliwościami rozwiązań problemów w ówczesnej ochronie przeciwpożarowej. Ze zjazdu wróciłem pełen optymizmu i wiary, że nasze zamiary są słuszne i należy je bezwzględnie realizować.

W niedługim czasie po powrocie do Wrocławia poprosiłem komendanta rejonowego Wrocław Stare Miasto o zorganizowanie spotkania naszej grupy z oficerami komend rejonowych z miasta Wrocławia i niektórymi oficerami komendy wojewódzkiej. Takie spotkanie odbyło się w siedzibie komendy. Z naszej strony obecni byli kol. kol. Januszkiewicz, Engel, Jaworski i ja, natomiast wśród uczestniczących niektórzy komendanci rejonowi oraz kilku oficerów z komendy wojewódzkiej. Obecnym zostały przedstawione główne cele i zamierzenia dotyczące zmian. Skierowaliśmy też apel o pomoc i czynne uczestnictwo przy pracach dot. zmian organizacyjnych. Istotnie, deklaracji włączenia się do prac i pomocy naszej grupie nie brakowało, lecz ku naszemu zaskoczeniu na deklaracjach się zakończyło. Jedyną spośród tego grona osobą, która autentycznie włączyła się czynnie do naszej grupy, był Stanisław Ręcławowicz — komendant rejonowy straży pożarnych Wrocław Krzyki, który działał czynnie przy pracach tworzenia projektu ustaw o Państwowej Straży Pożarnej i o ochronie przeciwpożarowej do chwili ich uchwalenia przez Sejm. Na podkreślenie zasługuje fakt, że był to zaledwie drugi oficer (obok Januszkiewicza) ze struktur terenowych straży pożarnych, który zadeklarował uczestnictwo spośród kilkunastu innych, przełamując barierę oba- 
wy i wątpliwości. Wówczas słabo znałem kol. Stanisława, lecz w krótkim czasie uświadomiłem sobie, że jest to osoba, którą przekonują nasze zamierzenia, wizjoner nowoczesnych rozwiązań, prekursor systemów informatycznych w Straży Pożarnej, dobry organizator i skuteczny w naszych poczynaniach.

W marcu 1990 r. nasza nieformalna grupa składała się z następujących osób: z Wrocławia - Ryszard Januszkiewicz, Eugeniusz Engel, Stanisław Ręcławowicz, Stanisław Mierzwa, Andrzej Jaroszek; z Wałbrzycha - Eugeniusz Zajączkowski, Józef Modras: ze strony NSZZ „Solidarność” — Krzysztof Wojtulski, Zdzisław Sołowin, Wiesław Jaworski, Marek Pawlak.

Naszą sytuację z powodzeniem opisuje sparafrazowane słynne powiedzenie, wypowiedziane $\mathrm{w}$ innych okolicznościach i w innym czasie — ,uważam, iż nigdy w historii powojennego pożarnictwa, tak wielu może zawdzięczać tak wiele, tak nielicznym" - czyli Dolnośląskiemu Zespołowi Redakcyjnemu. Myślę, że też czytelnik śledzący różne relacje z okresu tworzenia przepisów ustawy będzie miał ogromny dylemat co do liczby ojców sukcesu, bo ich grono do końca 1990 r. urosło o tych, co samodzielnie, wymyślili i zaproponowali podstawy przemian w ochronie przeciwpożarowe - mając mgliste pojęcie o prawie, a cóż dopiero o jego tworzeniu.

Wymieniony podstawowy skład osobowy naszego zespołu pożarników przetrwał w niezmienionym składzie do chwili zakończenia opracowania podstawowych wersji projektów ustaw o Państwowej Straży Pożarnej i ochronie przeciwpożarowej. Na podkreślenie zasługuje fakt, że przez cały okres pozostawaliśmy grupą pracującą całkowicie społecznie, a jedyną organizacją, która objęła nad nami patronat, była Krajowa Sekcja Pożarnictwa NSZZ „Solidarność”. Każdy z nas miał swoją wizję i przekonanie, co trzeba zrobić, ale nie do końca wiedział jak. Opracowanie od podstaw projektu przepisu prawnego rangi ustawowej wymagało wiedzy teoretycznej i umiejętności łączenia wielu dziedzin prawa. Myślę, że wielu teoretyków prawa potwierdzi zasadę, że przepis prawny, szczególnie rangi ustawowej, ma być wyrazisty co do woli ustawodawcy, w brzmieniu zrozumiałym dla tych, którzy będą go stosować w praktyce, co nie jest zadaniem łatwym. Wiele naszych spotkań było mało produktywnych, a dyskusje natury akademickiej kończyły się znaczną różnicą zdań, co uniemożliwiało wypracowanie konkretnej formy i treści. $Z$ całą mocą chcę podkreślić, że nie umniejszam i daleki pozostaję od kwestionowania zasobu wiedzy, intelektu, chęci, odwagi i determinacji każdego z wymienionych kolegów pożarników, ale prawda pozostaje niewzruszona, byliśmy sami i zbyt słabi oraz nieprzygotowani do wykonywania tak trudnego pod względem prawnym zadania.

Uznałem, że pozostaje tylko jedno — udać się do pracowników naukowych Wydziału Prawa i Administracji Uniwersytetu Wrocławskiego i prosić o pomoc. Tak też uczyniłem i wraz z kol. Ręcławowiczem udałem się na umówione wcześniej spotkanie z ówczesnym rektorem Uniwersytetu Wrocławskiego prof. dr. hab. Mieczysławem Klimowiczem. Po przedstawieniu celu naszego spotkania rektor nawiązał kontakt z dziekanem Wydziału Prawa prof. dr. hab. Januszem Trzcińskim 
(wówczas już posłem, który był wprowadzony w nasze zagadnienia podczas mojego spotkania w Sejmie). Profesor sprawil, że zostaliśmy przekierowani do konkretnych osób, pracowników naukowych tego Wydziału, tj. prof. dr. hab. Leona Kieresa, a następnie do prof. Włodzimierza Gromskiego, prof. Tadeusza Kocowskiego i mgr. Macieja Lamparskiego. Do tego grona dołączył dr inż. Mieczysław Cenin, choć jego związki ze Stanisławem Ręcławowiczem datują się znacznie wcześniej. Dzisiaj nie jestem w stanie określić, ile czasu poświęciłem na osobiste spotkania z osobami, które wymieniłem, aby przekonać je o konieczności współpracy z naszym zespołem. Do współpracy ostatecznie doszło i w dość krótkim czasie nasz zespół pozyskał ogromny kapitał intelektualny, a prace przy tworzeniu ustaw o PSP nabrały tempa, choć na konkretne efekty musieliśmy poświęcić dużo czasu i cierpliwości.

Doszło do fuzji dwóch światów — praktyki i wizji przyszłości oraz teorii i nauki. Połączenie tych dwóch sił spowodowało, że dokonał się ogromny historyczny postęp w spojrzeniu na przyszłą strukturę organizacyjną PSP w skali niespotykanej od 1918 r., a wymierzoną w XXI w. Definitywnie odrzucona została propozycja prac przy obowiązującej ustawie o ochronie przeciwpożarowej. Stanowisko pracowników naukowych było jednoznaczne — należy zacząć pisać od pierwszego artykułu całkowicie nową ustawę o Państwowej Straży Pożarnej — z pełnymi konsekwencjami. I tak też się stało. Poszczególne zapisy kolejnych artykułów były wielokrotnie korygowane, omawiane i przepisywane albo redagowane całkowicie od nowa z uwagi na zmieniającą się rzeczywistość w naszym kraju. Atmosfera spotkań przebiegała często bardzo burzliwie. Chodziło głównie o doprecyzowanie zadań przyszłej PSP oraz struktur organizacyjnych na szczeblu powiatu województwa i kraju. Zgodnie przyjęliśmy, że do naszej przyszłej ustawy trafi (po pewnych korektach) pragmatyka służbowa zaproponowana w ustawie o Policji. Godne najwyższego podziwu są postawy osób z grona naukowców, którzy wobec nas, praktyków, wykazywali zrozumienie, cierpliwość, a także bolesną konsekwencję. Nie pomylę się zbytnio, jeśli stwierdzę, że liczbę odbytych spotkań można było liczyć w dziesiątki, a spędzonych godzin w setki. W niedługim czasie okazało się, że zachodzi konieczność przeprowadzania konsultacji niektórych artykułów projektu ustawy z zakresu prawa cywilnego, pracy, administracyjnego, karnego, finansowego. Myślę, że i tym razem nie zawiodłem kolegów z zespołu w oczekiwaniach i pozyskałem życzliwych nam konsultantów w osobach prof. Edwarda Gniewka, prof. Zdzisława Kubota, śp. prof. dr. Zygmunta Masternaka, prof. Barbary Adamiak, prof. Marka Bojarskiego i dr. Stanisława Rogowskiego. Udział pracowników naukowych, w szczególności prof. Gromskiego, prof. Kocowskiego, dr. Cenina i mgr. Lamparskiego, był bardzo aktywny do ostatnich dni uchwalania naszych ustaw przez Sejm.

W miarę jak postępowały prace przy tworzeniu projektu ustawy, rosło zainteresowanie środowiska strażackiego. Wyrażało się to w różny sposób — od pełnej akceptacji do totalnej krytyki. Miało to miejsce od chwili, kiedy w maju 
1990 r. przedstawiłem na spotkaniu z kadrą komendy wojewódzkiej i nie tylko główne założenia do projektu ustawy o PSP. Zaniepokojenie, i to o znacznej wymowie społecznej, zaczęli wykazywać również funkcjonariusze pożarnictwa zatrudnieni w jednostkach resortowej ochrony przeciwpożarowej, gdyż przyjęte założenia w ustawie o PSP nie przewidywały innej struktury poza państwową. Wreszcie ze strony związków zawodowych uaktywnili się niektórzy działacze przeciwni podporządkowaniu przyszłej struktury PSP Ministrowi Spraw Wewnętrznych, mimo że byłoby to sprzeczne z zapisami ustawy o tym urzędzie. Nie brakowało też zwolenników podporządkowania straży pożarnej jednostkom samorządowym. Ta napięta nieco atmosfera nie stanowiła dla nas przeszkody, żeby kontynuować z pełną determinacją prace nad naszym projektem ustawy. Jestem głęboko przeświadczony, że ze strony służbowej największy wkład pracy przy opracowywaniu projektu ustawy o PSP wnieśli: Józef Modras, Stanisław Ręcławowicz i Andrzej Jaroszek. Było nam też wiadomo, że Komenda Główna pracuje dość intensywnie przy doskonaleniu obowiązującej ustawy o ochronie przeciwpożarowej, choć wiedza o pracy zespołu nad zupełnie nowym projektem ustawy o Państwowej Straży Pożarnej nie stanowiła tajemnicy dla komendanta głównego. Do poważnej i burzliwej konfrontacji doszło na spotkaniu w Józefowie na początku lipca 1990 r. pomiędzy komendantem głównym i jego przedstawicielami z niektórymi członkami naszego zespołu. Nadszedł czas, kiedy należało zadecydować, któremu z dwóch projektów ustaw nadaje się dalszy bieg legislacyjny. Wynikiem tego spotkania było ustalenie, że do dalszych prac zostanie skierowany projekt ustawy przygotowany przez Dolnośląski Zespół Redakcyjny. W czasie zjazdu Krajowej Sekcji Pożarnictwa NSZZ „Solidarność” w październiku 1990 r. który odbył się w Poznaniu, wykorzystując sprzyjające okoliczności, przekazałem projekt naszej ustawy kandydatowi na prezydenta RP Lechowi Wałęsie. Następnie projekt ten przekazano również Ministrowi Spraw Wewnętrznych, który wdrożył oficjalną drogę rządową do konsultacji międzyresortowych. Szybko okazało się, że była to „droga przez mękę”, więc pozostała nam tylko „inicjatywa poselska”. Pierwszą taką próbę zainicjowała posłanka Anna Dynowska, lecz w konsekwencji bieg legislacyjny nadany został oficjalnie przez posła prof. Bronisława Geremka. Pierwszym posłem sprawozdawcą został Andrzej Kosmalski, który z uwagi na zły stan zdrowia został bardzo skutecznie zastąpiony przez posła dr. Henryka Michalaka.

Zostałem upoważniony przez komendanta głównego Straży Pożarnych i przewodniczącego KSP NSZZ „Solidarności” do reprezentowania stanowiska Komendy Głównej i Związku w pracach komisji sejmowych: Prac Ustawodawczych oraz Administracji i Spraw Wewnętrznych, nad projektami ustawy o Państwowej Straży Pożarnej i ustawy o ochronie przed pożarami, która w dalszych pracach legislacyjnych została zastąpiona projektem ustawy o ochronie przeciwpożarowej. Projekt ten został przygotowany w dużej mierze przez posła Michalaka oraz Dolnośląski Zespół Redakcyjny. 
Tym sposobem przez sześć miesięcy uczestniczyłem wspierany przez kolegów z zespołu w intensywnych pracach legislacyjnych, współpracując głównie z posłem sprawozdawcą, a także $\mathrm{z}$ wieloma wspaniałymi osobistościami świata polityki i nauki. Mimo wielu trudności i przeciwności przy tworzeniu normy prawnej środowisko pożarnicze w porę uświadomiło sobie, że nieodzowna pozostaje szeroko zakrojona pomoc i informacja wśród załóg jednostek organizacyjnych oraz parlamentarzystów z całego kraju.

W rezultacie Sejm X kadencji projekty naszych ustaw uchwalił w dniu 24 sierpnia 1991 r. Na uwagę zasługuje jednomyślność posłów — ustawa o ochronie przeciwpożarowej nie miała głosów przeciwnych, a ustawa o Państwowej Straży Pożarnej miała ich zaledwie osiem. Tym samym stworzone zostały podwaliny do utworzenia i organizacji Krajowego Systemu Ratowniczo-Gaśniczego, z przyszłych struktur Państwowej Straży Pożarnej, ochotniczych straży pożarnych i innych podmiotów.

Tą drogą składam serdeczne podziękowania wszystkim, którzy przyczynili się do opracowania projektów naszych ustaw - pracownikom Uniwersytetu Wrocławskiego: prof. Włodzimierzowi Gromskiemu, prof. Tadeuszowi Kocowskiemu, dr. Mieczysławowi Ceninowi, mgr. Maciejowi Lamparskiemu; kolegom — Józefowi Modrasowi i Stanisławowi Ręcławowiczowi, a także Ryszardowi Januszkiewiczowi, Eugeniuszowi Englowi i Krzysztofowi Wojtulskiemu, Zdzisławowi Sołowinowi, Wiesławowi Jaworskiemu oraz Markowi Pawlakowi. Na szczególną uwagę środowiska strażackiego zasługują postawy pierwszego posła sprawozdawcy pana Andrzeja Kosmalskiego oraz nieżyjącego już posła Henryka Michalaka.

\section{HOW WERE “THE FIRE ACTS” CREATED — REMINISCENCE}

\section{Summary}

The article outlines the historical aspect of the creation of the Act of the State Fire Service and the Act of Fire Protection. The bills were elaborated by the Social Editorial Team in 1990. The Social Editorial Team consisted of scientists from the Faculty of Law, Administration and Economics from the University of Wrocław and firefighters from Wrocław and Wałbrzych. 